Крисак А. I. [1; ORCID ID: 0000-0002-9834-8712], д.е.н.

${ }^{1}$ Національний університет водного господарства та природокористування, Рівне

\title{
КРАУДІНВЕСТІНГ - ФІНАНСОВИЙ ІНСТРУМЕНТ ДЛЯ ЗАБЕЗПЕЧЕННЯ РЕКУЛЬТИВАЦІї ЗЕМЕЛЬ
}

У статті обгрунтовано, що з метою покращення екологічного стану земель існує потреба пошуку новітніх фінансових інструментів для забезпечення заходів 3 проведення рекультивації земель. Проаналізовано теоретичне підгрунтя рекультивації порушених земель на основі законодавчих актів України. Доведено необхідність формування умов відтворення та охорони рекультивованих земель із застосуванням краудінвестінгу як нового фінансово-економічного інструменту. Визначено найбільш поширене змістовне наповнення понятійно-категорійного терміну краудінвестінгу. Встановлено головні аргументи, що дозволяють скористатися краудінвестінговою платформою: для інвестора - низький поріг входження для реалізації бізнес-проекту та отримання майбутніх зисків (акції, активи, бонуси, частка прибутку від запровадженого проекту, в тому числі виторг від куплених цінних паперів створеної компанії прямо на краудінвестінговому майданчику); для стартапера - при нестачі стартового капіталу можливість отримати фінансування із набагато нижчим відсотком та швидше, ніж в банку, при чому без наявності кредитної історії. На основі використання цифрових технологій представлено організаційний процес укладання угоди про надання послуг щодо залучення інвестицій з краудінвестінговою платформою між учасниками краудінвестингу, а також договору інвестування між безпосереднім інвестором та юридичною чи фізичною особою, яка залучає засоби, у формі прийняття оферти (іï акцепту). Подано порівняльну візуалізацію краудінвестінгу з облігаціями і фондової біржею. Здійснено ретроспективний аналіз появи краудінвестінгу у США та проаналізовано умови для становлення і розвитку краудінвестінгу в Україні. Встановлено, що поєднання електронних можливостей, інформаційних та фінансових технологій дає змогу зацікавити суспільство та залучити широку онлайн-громадськість до використання краудінвестінгових платформ 3 метою проведення рекультивації порушених земель, що матимуть більший рівень капіталізації земель завдяки можливості повернення їх до господарської діяльності. 
Визначено особливу актуальність потреби рекультивації земель для поліських регіонів 3 покращенням екологічного стану лісових угідь, порушених внаслідок несанкціонованого видобування бурштину. Доведено, що при розробці механізмів щодо охорони та відтворення земельних ресурсів у руслі кореспондування Цілей сталого розвитку, краудівестінг варто застосовувати 3 метою залучення та мобілізації ресурсів, які зосереджуються на краудплатформі, а також зацікавленості значної кількості стейкхолдерів для вирішення проблемних питань стосовно рекультивації порушених земель та визначення екологоекономічного напряму стратегування земельних відносин на перспективу.

Ключові слова: рекультивація; відновлення земель; краудплатформа; інвестування.

Вступ. В умовах поглиблення економічної кризи посиленої коронакризою, анексією АР Крим, продовженням військових дій на тимчасово окупованих територіях, зниженням дохідної частини малого та середнього бізнесу, а також зменшенням купівельної спроможності населення, в Україні відбуваються трансформаційні процеси, що пов'язані з розробкою механізмів щодо охорони та відтворення земельних ресурсів та пошуком нових фінансових інструментів для забезпечення заходів з проведення рекультивації земель.

Питаннями рекультивації порушених земель та розробці фінансово-економічних механізмів використання та охорони земельних ресурсів уже тривалий час займаються вчені провідних наукових установ таких як: ДУ «Інститут природокористування та сталого розвитку Національної академії наук України», ННЦ «нститут ґрунтознавства та агрохімії імені О. Н. Соколовського», ННЦ «Інститут аграрної економіки» НААН України, ДУ «Інститут економіки та прогнозування НАН України», Національний університет водного господарства та природокористування, Інститут економіки промисловості НАН України та ін. Однак для активізації роботи інвесторів варто більше уваги звернути на сучасні фінансові інструменти, що забезпечать розширення інвестиційних можливостей стейкхолдерів на основі цифрових технологій.

Мета і завдання дослідження. Обґрунтувати використання такого фінансового інструменту як краудінвестінг, що дасть можливість залучати інвестиційні ресурси для покращення екологічного стану земель.

Основна частина. Згідно ст. 166 Земельного кодексу України рекультивація порушених земель - це комплекс організаційних, технічних і біотехнологічних заходів, спрямованих на відновлення 96 
ґрунтового покриву, поліпшення стану та продуктивності порушених земель [1]. У відповідності до ст. 52 Закону України «Про охорону земель» рекультивація земельних ділянок здійснюється шляхом пошарового нанесення на малопродуктивні земельні ділянки або ділянки без ґрунтового покриву знятої ґрунтової маси, а в разі потреби - і материнської породи в порядку, який забезпечує найбільшу продуктивність рекультивованих земель [2]. Роботи із зняття, складування, збереження та нанесення ґрунтової маси на порушені земельні ділянки здійснюються за рахунок фізичних та юридичних осіб, з ініціативи або вини яких порушено ґрунтовий покрив, а роботи 3 нанесення знятої ґрунтової маси на малопродуктивні землі здійснюються за бажанням власників або землекористувачів, у тому числі орендарів, цих земельних ділянок за їх рахунок [2].

Новим сучасним фінансовим інструментом у цій галузі може стати краудінвестінг. У світі краудінвестінг користується популярністю з метою залучення капіталу або вкладу коштів як від фізичних, так і юридичних осіб, для розвитку нового стартапу.

Краудінвестінг - це залучення фінансування в який-небудь малий або новий бізнес. Дослівно термін перекладається, як фінансова допомога від натовпу. Тобто, це гроші, які збираються 3 великої кількості зацікавлених інвесторів в різній кількості для фінансування одного проекту. У разі реалізації стартапу, кожен інвестор гарантовано стає акціонером нової компанії. Такий тип інвестування дозволяє боротися 3 однією 3 головних проблем стартапів - нестачею стартового капіталу [3]. Для інвестора головним аргументом $€$ низький поріг, що дозволяє скористатися краудінвестінговою платформою, а для стартапера - можливість отримати фінансування із набагато нижчим відсотком, ніж в банку. Причому інвестором може стати кожен, хто готовий внести в проєкт мінімально-визначений вклад, а стартаперу скористатися коштами швидко і без кредитної історії. У світовому розумінні краудінвестінг це бізнес на спільні кошти, коли декілька інвесторів вкладають свій капітал в бізнес-проєкт для отримання доходу або інших зисків у майбутньому [4]. Особа, що вкладає свої кошти у цей бізнес-проект перетворюється в акціонера, який зацікавлений в подальшому розвитку бізнес-проекту, адже вона матиме можливість отримувати прибуток від вкладених інвестицій та набувати часткових повноважень у прийнятті рішень. Використання краудінвестінгу вважається більш серйозним інструментом фінансування ніж інших краудингових платформ (наприклад, таких як краудсорсинг, краудфандинг, краудлендинг тощо), оскільки широке коло 
мікроінвесторів безпосередньо береться «в долю» 3 усіма наслідками щодо вигід (акцій, активів, бонусів, частки прибутку від запровадженого проекту, в тому числі виторгу від куплених цінних паперів створеної компанії прямо на краудінвестінговому майданчику), але разом з тим поширюються також і ризики. Однак, i інвестор і стартапер мають одну і ту ж, спільну мету, якою є їхня зацікавленість у фінансовому успіху бізнес-проєкту.

Бути учасником краудінвестингу не складно. Фізична або юридична особа, що хоче залучити кошти на розвиток бізнеспроекту заключає угоду про надання послуг щодо залучення інвестицій з краудінвестінговою платформою. Аналогічну процедуру проходить інвестор щодо сприяння в інвестуванні. Надалі укладається ще одна угода - договір інвестування між безпосереднім інвестором та юридичною чи фізичною особою, яка залучає засоби, у формі прийняття оферти (iї акцепту). Для того щоб це відбулося сторонам необхідно здійснити два важливих кроки: 1) особі, що залучає інвестиції, опублікувати на платформі інвестиційну пропозицію (оферту), 2) інвестору ії прийняти (акцептувати). Таким чином заключається угода не в паперовому, а в цифровому форматі. Залежно від обраного виду краудінвестінгу i суттєвих умов використовуються різні типи договорів. Зокрема, при позиці - договір позики, де істотними умовами виступають строк, сума позики, відсотки за позикою, штрафні санкції у випадку невиконання умов договору особою, що залучає інвестиції (або пені за кожен день протермінування, чи одноразовий фіксований штраф, або і те і інше разом) [4]. Такий процес дещо нагадує облігаційні позики, де також $€$ емітент і позичальник, вони також можуть домовитися про проміжні виплати і розмір відсотків. Платформа краудінвестінгу як за технічними характеристиками, так і візуально нагадує фондову біржу. На ній $є$ графіки зростання та падіння емітентів, тобто відкриті матеріали для інвесторів, пропонується статистика за вкладами. Як у випадку із фондовим ринком, краудінвестінгова платформа виступає посередником між вкладником і позичальником, і бере на себе обов'язки з перевірки наданого бізнесу. Але краудінвестинг має свої переваги, які полягають в тому, що він реалізований набагато простіше, ніж фондовий ринок, і не потребує наявності проміжних ланок у вигляді значної кількості брокерів і трейдерів.

Першою краудінвестінговою платформою вважається американська платформа EquityNet, створена у 2005 році, якою вже через 9 років скористалися 45000 інвесторів із загальною сумою вкладів 240 мільйонів доларів США. Там же, в США, в період з 2005 
по 2012 роки розвивалися й інші популярні сайти колективних вкладників: AngelList, Seedlnvest, FundersClub, CircleUp. Справжній бум краудінвестінг пережив у 2012 році, коли Барак Обама підписав знаковий закон, який підтримує малий бізнес. До цього часу колективне інвестування в США було скоріше за все підпільним методом заробітку [5].

В Україні краудінвестінг тільки набирає оберти популярності серед стейкхолдерів.

За твердженням фахівців Інституту економіки промисловості Національної академії наук України теоретично в Україні склалися всі умови для становлення і розвитку краудінвестінгу. Цьому сприяв бурхливий розвиток соціально-мережевих відносин і комунікацій, в тому числі фінансових. Так за даними Citibank i Imperial College London, які щорічно розраховують індекс готовності країн до використання цифрових грошей (Digital Money Readiness Index), Україна по готовності входить в другу із чотирьох, групу країн. 3 кожним роком все більша кількість громадян України користується українськими цифровими платформами такими, як «Prom.ua», «Rozetka», «OLX», «BlaBlaCar», «Work.ua», «Rabota.ua», «HeadHunter», «Freelance.ua», «Monobank», «Приват24», «UKRSIB online», «Ощад 24/7» й інших банків України [6], а також «Prozorro», «Setam», «DomRia», «AvtoRia», «Startup.Network» тощо, задовільняючи свої економічні потреби. 3'являються нові професії та форми організації праці, все більшого розвитку набуває віддалений характер роботи, мережевий фріланс із оплатою праці шляхом використання електронних платіжних систем, поширення соціальних мереж, застосування мобільних додатків, що також $є$ стимулятором для участі в крауд-фінансуванні.

Краудінвестінг $€$ аналогом венчурного інвестування, де замість венчурного інвестора виступають приватні особи. В умовах любої кризи завжди знайдуться компанії, які характеризуються зростаючими показниками. Зараз, наприклад, затребуваними $\epsilon$ електронні комунікації, служби доставки, фудтех-проєкти, онлайннавчання. I їм також потрібні кошти для розвитку, які можна залучати в тому числі завдяки таким інструментам.

\section{Вдале поєднання інтернет-можливостей, сучасних}

інформаційних та фінансових технологій дає змогу зацікавити суспільство та залучити широку онлайн-громадськість до використання краудінвестінгових платформ, що найбільш повною мірою відповідає альтернативному варіанту досягнення збалансованості земельних відносин з врахуванням інформаційних технологій та посилення екологізації розвитку територій. Порушені 
землі доречно і необхідно повертати до господарського обороту шляхом проведення рекультивації земель. Рекультивовані земельні ділянки матимуть більший рівень капіталізації завдяки можливості здійснення на них господарської діяльності. А для поліських регіонів, наприклад, покращення екологічного стану лісових угідь, порушених внаслідок незаконного видобування бурштину, забезпечить саме комплекс заходів з рекультивації. Загалом, за статистичною інформацією [7], в Україні у 2020 році площі земель, яким необхідна рекультивація досягнули 141 тис. га. Але, на жаль, процеси рекультивації в Україні проходять дуже мляво і за останні роки практично характеризуються нульовими показниками. Натомість, великий досвід рекультивації земель накопичений у США та Західній Європі, де від 30 до 40\% порушених земель відновлено з метою відтворення продуктивних угідь та охорони навколишнього середовища. Тому для розвитку природоохоронної сфери доцільно впроваджувати та вдосконалювати існуючі методи і стимули еколого-економічного регулювання земельних відносин, враховуючи кращі світові практики та інноваційні цифрові технології.

Висновки. Таким чином, при розробці механізмів щодо охорони та відтворення земельних ресурсів у руслі кореспондування Цілей сталого розвитку, краудівестінг варто застосовувати 3 метою залучення та мобілізації ресурсів, які акумулюються на краудплатформі, а також зацікавленості значної кількості стейкхолдерів для вирішення проблемних питань стосовно рекультивації порушених земель та визначення екологоекономічного напряму стратегування земельних відносин на перспективу.

1. Земельний кодекс України. 2. Про охорону земель : Закон України. 3. Краудінвестінг. URL: https://moneyveo.ua/uk/article/ (дата звернення: 13.03.2021). 4. Краудивестинг по-русски: как это работает и какие есть риски. URL: https://spark.ru/startup/redaktsiya-spark-ru/blog/54509/ (дата звернення: 13.03.2021). 5. Что такое краудинвестинг. URL: https://wow.karma.red/ (дата звернення: 13.03.2021). 6. Богуцька 0. Возможно ли развитие краудинвестинга в Украине? URL: https://blog.liga.net/user/obogutskaya/article/33786 (дата звернення: 13.03.2021). 7. Статистичний щорічник. URL: http://www.ukrstat.gov.ua (дата звернення: 13.03.2021).

\section{REFERENCES:}

1. Zemelnyi kodeks Ukrainy. 2. Pro okhoronu zemel : Zakon Ukrainy. 3. Kraudinvestinh. URL: https://moneyveo.ua/uk/article/ (data zvernennia: 13.03.2021). 4. Kraudivesting po-russki: kak eto rabotaet i kakie est riski. URL: https://spark.ru/startup/redaktsiyaspark-ru/blog/54509/ (data zvernennia: 13.03.2021). 5. Chto takoe kraudinvesting. URL: https://wow.karma.red/ (data zvernennia: 13.03.2021). 6. Bohutska 0. Vozmojno 
li razvitie kraudinvestinga U Ukraine? https://blog.liga.net/user/obogutskaya/article/33786 (data zvernennia: 13.03.2021). 7. Statystychnyi shchorichnyk. URL: http://www.ukrstat.gov.ua (data zvernennia: 13.03.2021).

Krysak A. I. [1; ORCID ID: 0000-0002-9834-8712], Doctor of Economics

${ }^{1}$ National University of Water and Environmental Engineering, Rivne

\section{CROWDINVESTING AS A FINANCIAL INSTRUMENT TO ENFORCE THE RECLAMATION OF LANDS}

This article substantiates that there is a need to find modern financial instruments for measures of lands reclamation in order to improve the ecological condition of lands. The author analyzes theoretical grounds of reclamation of distorbed lands based on the legislation of Ukraine. The provided arguments prove that it is necessary to build conditions for the reproduction and protection of reclaimed lands using means of crowdinvesting as a new financial and economic instrument. The article defines the most widespread and meaningful definition of the crowdinvesting term with its notions and subcategories. The author manifests solid arguments which facilitate the usage of the crowdinvesting platform: for the investor - the low entry threshold in order to implement a business project and obtain the interest in the future (such as shares, assets, bonuses, a part of the profit in the completed project including benefits from acquired securities from the created company, directly within the crowdinvesting forum); for the srat-up owner - considering the luck of the start-up funds, it is a possibility to obtain funding with significantly lower percentage and faster than in the bank, moreover without the requirement to demonstrate the credit history. The article presents the process of the crowdfunding contract settlement between the crowdinvesting platform and crowdinvesting participants based on digital technologies, as well as the funding contract between the direct investor and the legal or physical entity which obtains funds by accepting the offer. There is a comparative visualization of the crowdinvesting with obligations and stock exchanges. The author gives retrospective analysis of the crowdinvesting origins in USA and analyses preconditions for the crowdinvesting emergence and development in Ukraine. The article determines that the combination of digital opportunities with informational and financial technologies allows to increase the interest from the society and involve a wide online community to start participating in crowdinvesting platforms in order to provide the reclamation of disturbed lands which will obtain a better level of capitalization thanks to the fact that it is possible to bring them back to the economic activity. The author reinforces a special need to reclaim lands for 
the Polissya region with the improved ecological state of the forest lands which was damaged because of the illegal quarrying of the amber. It is proved that the development of the mechanisms of the land resources protection and restoration within the Goals of the sustainable development should rely on the crowdinvesting in order to accumulate and obtain resources from the crowd platform; it should also be used to encourage more stakeholders to solve problems of the reclamation of the disturbed lands and to determine the ecological and economic directions of the land relations strategies for the future.

Keywords: reclamation; lands restoration; crowd platform; investing.

Крисак А. И. ${ }^{[1 ; 0 R C I D ~ I D: ~ 0000-0002-9834-8712], ~}$ Д.э.н.

${ }^{1}$ Национальный университет водного хозяйства и природопользования, г. Ровно

\title{
КРАУДИНВЕСТИНГ - ФИНАНСОВЫЙ ИНСТРУМЕНТ ОБЕСПЕЧЕНИЯ РЕКУЛЬТИВАЦИИ ЗЕМЕЛЬ
}

\begin{abstract}
В статье обосновано необходимость улучшения экологического состояния земель при использовании новейших финансовоэкономическых инструментов, таких как краудинвестинг, которые обеспечат проведение рекультивации земель. Определены главные аргументы, которые позволяют воспользоваться краудинвестинговой платформой инвесторам и стартаперам. Представлено организационный процесс составления договора о предоставлений услуг по получению инвестиций посредством краудинвестинговой платформы, а также сравнительная визуализация краудинвестинга с облигациями и фондовой биржей. Ретроспективно проанализоровано появление краудинвестинга в США и условия его возникновения и развития в Украине. Определено, что сочетание электронных возможностей, информационных и финансовых технологий позволяет заинтересовать общество и привлечь широкую онлайн-общественность к использованию краудинвестингових платформ с целью проведения рекультивации нарушенных земель, будут иметь больший уровень капитализации земель благодаря возможности возвращения их к хозяйственной деятельности.
\end{abstract}

Ключевые слова: рекультивация; восстановление земель; краудплатформа; инвестирование. 